\title{
MENGGALI POTENSI MINAT DAN BAKAT SISWA INKLUSIF DI SEKOLAH METAL DENGAN PARENTING, KONSELING, DAN SKILL EDUCATION
}

ACHMAD FARID

SMP Negeri 27 Surabaya

faridachmad65@gmail.com

\begin{abstract}
ABSTRAK
Tujuan penelitian ini adalah siswa dapat mengetahui cara menggali potensi minat dan bakat siswa ABK di SMP Negeri 27 Surabaya. Kemudian selanjutnya siswa dapat mengetahui kendala yang dihadapi sekolah dalam menggali potensi minat dan bakat siswa ABK di SMP Negeri 27 Surabaya dan dapat mengetahui upaya sekolah dalam menggali minat dan bakat siswa ABK di SMP Negeri 27 Surabaya. Metode yang dipakai dalam penulisan makalah ini deskriptif yaitu dokumentasi dan kajian pustaka/Literatur. Kajian pusta literatur di peroleh dari buku-buku di perpustakaan dan beberapa jurnal yang seseuai dengan tema artikel yang penulis buat. Pada awalnya penulis mengindentifikasi permasalahan pembelajaran ABK melalui pengamatan dan wawancara, serta menganalisis secara lengkap hasil tersebut secara deskriptifif. Hasil tindak lanjut menunjukan bahwa antara guru pembimbing khusus dalam melihat karakteristik siswa ABK dilihat dari hasil pembelajaran, rasa ingin tahu, serta sikap siswa dalam keseharian. Guru khusus dalam prakteknya banyak memberikan kegiatan yang bersifat keterampilan ( Skill education) untuk dapat mengetahui berbagai potensi minat bakat siswanya, demikian juga kerja sama sekolah dengan orang tua (Parenting) sangat menentukan minat bakat anaknya, tentunya juga tidak terlepas dari bimbingan dan koseling dari Psikolog,baik melalui dialog maupun test kemampuan minat dan bakat sesuai dengan anak-anak berkebutuhan khusus. Rekomendasi ini diberikan kepada siswa yang berkebutuhan khusus untuk masuk ke SMA/K Negeri melalui jalur prestasi, jalur inklusi ,

Kata Kunci : Minat, Bakat, Inklusif, Parenting, Konseling, Skil Education
\end{abstract}

\section{PENDAHULUAN}

Siswa Anak Berkebutuhan Khusus ( ABK ) merupakan salah satu anugerah yang tiada ternilai yang Allah SWT berikan pada beberapa orang tua yang luar biasa. Berbagai keistimewaan yang dimiliki oleh setiap siswa dapat dilihat dari fisik, bakat, potensi, sifat, kebutuhan ataupun karakteristik khusus. Karakteristik khusus yang tidak dimiliki siswa biasanya diartikan untuk siswa yang ABK. Menurut teoritukus humanistik juga menyatakan "setiap manusia memiliki serangkaian perangai dan bakat-bakat yang mendasari perasaan dan kebutuhan individual serta memberikan perspektif yang unik dalam hidup kita”. (Desmita, 2009:270). Sama halnya dengan siswa ABK , mereka pada dasarnya mereka juga sama seperti individu siswa lain, mereka juga memiliki hak sama untuk dapat sukses dan berkembang dalam hidupnya dengan berbagai minat dan bakat yang mungkin banyak orang lain tidak miliki. 
Sekolah Menengah Pertama Negeri 27 Surabaya dikenal sebagai sekolah METAL (Mepet Tambak Angkatan Laut) karena lokasinya berada di daerah perumahan dinas angkatan laut ujung surabaya, merupakan salah satu sekolah reguler di surabaya yang di amanati untuk membina, membimbing dan mendidik siswa yang berkebutuhan khusus. Jumlah siswa ABK di SMP Negeri 27 Surabaya tahun pelajaran 2019 - 2020 sebanyak 46 siswa terdiri kelas $7=16$ siswa, kelas $8=16$ siswa dan kelas $9=14$ siswa, dari jumlah siswa tersebut hampir $80 \%$ orang tua siswa, kesadaran dan perhatian akan pendidikan terhadap anaknya sangat kurang, hal ini ditambah dengan tingkat sosial ekonomi rata - rata menengah kebawah sehingga orang tua kurang memahami dan mengetahui kelebihan - kelebihan yang dimiliki oleh anaknya yang luar biasa. Justru yang sering di keluhkan oleh orangb tua adalah kekurangan yang ada pada anaknya.

Dari permasalahan permasalahan itu sekolah berupaya untuk melakukan suatu kegiatan yang menumbuhkan dan memotivasi orang tua dalam menggali hal - hal yang positif dari putranya dan salah satunya adalah minat dan bakat putranya. Adapaun upaya sekolah untuk memfasilitasi kegiatan sekolah tersebut melalui PAK LISDU (Parenting, Konseling dan Life Skill Education ). Adapun kegiatan Parenting adalah proses pembelajaran pengasuhan interaksi antara orang tua dan anak yang meliputi aktivitas memberi petunjuk, memberi makan, memberi pakaian, melindungi anak saat mereka tumbuh berkembang. Parenting education merupakan pendidikan yang berkaitang dengan cara atau teknik pengasuhan atau mengasuh anak saat mereka tumbuh berkembang. Dalam parenting education ini memiliki tujuan meningkatkan pengetahuan dan ketrampilan orang tua dalam melaksanakan perawatan dan pengasuhan anak-anak mereka, serta meningkatkan kesadaran orang tua atau anggota keluarga lain sebagai pendidik yang pertama dan utama, di samping kegiatan parenting juga dilaksanakan kegiatan Konseling atau penyuluhan adalah proses pemberian bantuan yang dilakukan oleh seorang ahli (disebut konselor/pembimbing) kepada individu yang mengalami sesuatu masalah (disebut konseli) yang bermuara pada teratasinya masalah yang dihadapi klien, demikian juga dilaksanakan kegiatan pendidikan kecakapan hidup menurut Tim BBE Depdiknas (2015) pendidikan kecakapan hidup (Life Skills Education) merupakan proses pendidikan yang mengarah pada pembekalan kecakapan seseorang, untuk mampu dan berani menghadapi problema hidup dan kehidupan secara wajar, tanpa merasa tertekan, kemudian secara proaktif dan kreatif mencari solusinya, sehingga akhirnya mampu mengatasi problema tersebut. Dari uraian diatas dapat menjadi suatu landasan bagi penulis tertarik untuk mengetahui bagaimana menggali potensi minat dan bakat pada siswa ABK di sekolah metal SMP Negeri 27 Surabaya. 


\section{METODE PENELITIAN}

Metode yang dipakai dalam penulisan makalah ini deskriptif yaitu dokumentasi dan kajian pustaka/Literatur. Kajian pusta literatur di peroleh dari buku-buku di perpustakaan dan beberapa jurnal yang seseuai dengan tema artikel yang penulis buat. Pada awalnya penulis mengindentifikasi permasalahan pembelajaran ABK melalui pengamatan dan wawancara, serta menganalisis secara lengkap hasil tersebut secara deskriptifif.

\section{HASIL PENELITIAN DAN PEMBAHASAN}

\section{Cara Sekolah dan Guru Dalam Menggali Minat dan Bakat Siswa ABK}

Di sekolah inklusi terdapat dua macam guru yaitu guru reguler atau guru mapel dan guru inklusi atau khusus. Pandangan guru reguler terkait cara mereka mengetahui karakteristik siswa ABK yang berada di kelas khususnya pada siswa dengan jenis lambat belajar dapat dikatakan bahwa mereka lebih melihat pada ciri khas atau karakteristik saat pembelajaran. Biasanya siswa ABK akan melihatkan perbedaan yang jelas dengan siswa lain pada pembelajaran meskipun itu pada siswa dengan jenis sama perbedaan dapat dilihat dari contoh kesulitan pada materi pembelajaran masing-masing anak.

Lain halnya dengan pandangan cara guru khusus dalam mengenal karakteristik setiap siswa ABK yang dibimbingnnya. Dari wawancara yang dilakukan dengan guru khusus dapat dinyatakan bahwa, guru khusus lebih memperhatikan dan memahami karakteristik siswa ABK yang dibimbingnya. Selain dengan melihat dari jenis kebutuhan siswa, guru khusus juga memperhatikan siswa ABK dalam keseharian bersikap, bertingkah laku, hal yang sering mereka lakukan atau tunjukkan dan respon pada setiap hal yang ada disekitar seperti tinggi rendahnya rasa ingin tahu mereka. Hal tersebut menjadi gambaran jelas bahwa antara guru reguler dan khusus prakteknya memiliki fokus yang berbeda-beda pada caranya mengenali karakteristik setiap siswa ABK yang dibimbing. Guru khusus lebih terlihat memiliki waktu yang lebih untuk mendampingi dan mamahami siswa ABK sehingga cara yang digunakan guru khusus bisa dikatakan lebih memliki penanganan khusus dalam menghadapi dan memperhati-kan karakteristik siswa ABK dibandingkan dengan guru reguler.

\section{Kendala Sekolah dan Guru dalam Melaksanakan Pembinaan Minat Bakat Anak Berkebutuhan Khusus Di SMP Negeri 27 Surabaya}

Berbagai kegiatan pembinaan yang berlangsung pasti memiliki kendala dalam bentuk besar ataupun kecil, baik oleh sekolah sendiri ataupun guru dalam sendiri. kepala sekolah menjadi informan dari kendala yang sekolah hadapi, sedangan guru khusus yaitu masih menjadi infroman guru utama, mengingat guru mapel yang lebih menyerahkan urusan minat bakat siswa khususnya siswa ABK dikleas 7 pada jenis kesulitan atau hambatan belajar pada guru khusus.

Bagi guru khusus sendiri menyatakan bahwa kendala yang dihadapi dalam melaksanakan pembinaan minat bakat terdiri dari berbagai macam hal yaitu dari sarana prasarana mulai dari ruangan yang inklusi yang masih menggunakna ruang perpustakaan terlebih lagi dalam satu ruangan terbagi menjadi dua bagian untuk dua 
tingkatan kelas sekaligus. Namun juga sarana praKepala Sekolaharana yang menunjang kegiatan pembinaan, diamana sekolah hanya memiliki tiga buah gitar, sehingga guru hanya mampu membina minat bakat siswa ABK pada hal yang sederhana juga seperti dalam keterampiplan tangan layaknya menggambar, membuat origami dll yang tidak membutuhkan sarana prasarana yang besar.

Disisi lain dengan kondisi siswa ABK yang memang sesuai dengan 14 Prosiding Seminar Nasional Reforming Pedagogy 2016 jenis kekurangan yaitu kesulitian atau lambat belajar juga menjadi hal yang tidak terpisahkan apabila siswa kerap kali membutuhkan bimbingan lebih karena pemahaman yang kurang. Menurut Ellis (2008:102) "Minat terbagi dalam dua jenis yang dapat dilihat dari segi waktu yaitu minat situasional dan pribadi". Hal ini sesuai dengan guru yang menyatakan bahwa selama ini kendala yang dihadapi terletak pada anak itu sendiri baik dari segi suasana anak atau mood dari anak atapun minat anak yang kerap kali berubah-ubah sehingga guru yang merasa mantap untuk berusaha mengoptimalkan minat bakat siswa kerap kali menjadi berfikir ulang kembali terkait minat bakat siswa ABK yang lebih tepat.

Berbeda dengan kendala yang dihadapi oleh guru yang telah diutarakan sebelumnya, Kepala Sekolah selaku kepala sekolah memiliki pandangan kendala tersendiri dalam melangsungkan upaya membina minat bakat siswa yang ditujukan untuk seluruh siswa yang ada di sekolah baik reguler maupun ABK. Kepala Sekolah merasa bahwa kendala yang dihadapi selama ini sesungguhnya yaitu kesiapan dari kemampuan guru yang perlu diasah dalam membina minat bakat anak, mengingat yang mereka ajar itu tidak hanya siswa reguler biasa namun juga terdapat siswa ABK

\section{Upaya Sekolah dalam Melaksanakan Pembinaan Minat dan Bakat Anak Berkebutuhan Khusus Di SMP Negeri 27 Surabaya.}

Tidak hanya guru khusus yang memiliki upaya untuk menemukan minat bakat siswa ABK, sekolah juga turut adil dalam menyokong usaha menemukan dan membina minat bakat siswanya. Selain guru khusus sekolah juga memiliki kesadaran penuh akan pentingnya minat serta bakat dari para siswanya yang perlu untuk dikembangkan. Dalam hal tersebut kepala sekolah yang pada kesempatan ini merupakan peimpinan tertinggi yang ada di sekolah mengutarakan upaya yang sekolah lakukan guna membina minat bakat siswa ABK yang ada di sekolahnya melaui wawancara yang dilakukan oleh tim ahli psikolog melalui kegiatan parenting. Dalam pelaksanaanya School parenting terdiri dari 5 langkah yaitu:

a. Perencanaan, Dalam tahap ini peneliti bersama-sama dengan guru bimbingan konseling menentukan beberapa hal, yaitu: Menentukan tema yang akan diangkat dalam kegiatan school parenting, menentukan peserta school parenting, menetukan waktu pelaksanaan, Menentukan pemateri atau fasilitator.

b. Pengorganisasian, Dalam tahap ini guru bimbingan dan konseling membagi tugas untuk melaksanakan kegiatan school parenting.

c. Pelaksanaan, Kegiatan school parenting dengan tema motivasi belajar dilaksanakan pada Sabtu, 07 April 2018 pukul 9.00-11.00. Dengan pemateri bapak 
Drs. Amanto,S.Psi. Dalam school parenting dibagi menjadi 4 sesi yaitu: pretsest, pembukaan, pemaparan materi, dan diskusi, penutup.

d. Hasil pelaksanaan school parenting

Adapun Hasil yang dicapai dalam pelaksanaan school parenting antara lain sebagai berikut:

1. Adanya kerja sama antara orang tua dan sekolah. Dengan adanya school parenting orang tua dan sekolah dapat bekerjsama dalam mendidikan anak, orang tua dapat menciptakan suasana rumah yang dapat mendukung pembelajaran anak disekolah, sehingga apa yang anak pelajari disekolah dapat mereka amalkan dalam kehidupan sehari- hari.

2. Orang tua dapat mengetahui permasalahan yang di hadapi anak di sekolah. School parenting merupakan salah satu media yang bisa digunakan untuk bertukar informasi antara orang tua dan sekolah, dengan begitu orang tua dan sekolah dapat bersama-sama mencari solusi atas permasalahan yang mereka hadapi.

3. Memberikan pengetahuan kepada orang tua tentang cara mendidik anak Tugas orang tua untuk mendidik anak sangatlah berat, Sedangkan masih banyak dari orang tua yang belum memahi bagaimana cara mendidik anak sesuai dengan masa perkembangannya dengan adanya kegiatan school parenting ini orang tua dapat lebih memahami bagaimana cara mendidik anak sesuai dengan tahap perkembangan mereka.

4. Sekolah dapat mengetahui bagaimana pola pendidikan anak dirumah. Dengan adanya school parenting sekolah dapat mengetahui bagaimana pendidikan karakter dalam keluarga. Khususnya sekolah ini merupakan sekolah Negeri dan Inklusi, sehingga sekolah harus bisa mengetahui apakah pendidikan karakter yang mereka dapatkan disekolah sudah mereka jalankan dalam kehidupan sehari-hari atau belum.

5.Dari hasil implementasi kegiatan parenting beberapa siswa ABK SMP Negeri 27 Surabaya berhasil masuk ke SMK Negeri Surabaya,jurusan TKJ, Desain Grafis, Perhotelan dll.

e. Evaluasi, langkah ini dimaksudkan untuk menilai atau mengetahuisejauh manakah program yang telah dilakukan dan telah mencapai hasilnya. Adapun berdasarkan hasil evaluasi dapat disimpulkan:

1. Antecedents, adalah penilaian terhadap sumber/ modal/input. Adapun input berupa sumber personil, sumber pembiayaan dan tujuan yang ingin dicapai secara kesluruhan dapat dibilang sudah baik.

2. Tahap transaksi adalah penilaian terhadap rencana kegiatan dan proses pelaksanaannya. Dalam perencanaan sudah berjalan sdengan baik akan tetapi ada hal yang harus diperbaiki seperti mengajak guru lain untuk ikut dalam perencanaan program. Dalam pelaksanaanya juga sudah cukup baik akan tetapi masih banyak hal yang harus diperbaiki contoh meningkatkan partisipasi orang tua dalam mengikuti program, meningkatkan kerja sama dengan guru lain, memasukkan kegiatan school parenting dalam kalender kegiatan sekolah dsb.

Out comes, adalah proses penilaian efek dari program, setelah pelaksanaan school parenting dikatakan belum begitu berhasil karena kegiatan ini belum bisa dilakukan 
secara rutin dan teratur sehingga kesadaran dari orang tua masih sparsial belum sepenuhnya.

Dari hasil kegiatan parenting yang dilakukan oleh pihak sekolah dengan orang tua siswa berkebutuhan khusus serta Psikolog berkesimpulan bahwa kunci dari semua ini adalah ikhlas. Jika ikhlas, orang tua bisa mencintai dan merawat anak yang berkebutuhan khusus tanpa mengeluh. "Karena ikhlas ada di dalam diri orang tua dan itu yang diberikan kepada anak,". ada orang tua yang tidak atau belum bisa menerima kondisi anaknya yang mengalami keterbatasan. Penolakan itu membuat mereka tidak ikhlas dalam mengasuh anak dan masih mematok standar yang sulit bagi si anak. Ketidak ikhlasan ini bisa juga datang dari perubahan kehidupan orang tua, contohnya ibu yang berhenti bekerja setelah memiliki anak berkebutuhan khusus. Akibatnya orang tua harus belajar menyesuaikan diri dengan keadaan, termasuk urusan finansial dan sosial demi anak."Saat tidak ikhlas, orang tua pasti akan cenderung emosional. Tidak jarang apapun yang terjadi akan salah di mata mereka," . Untuk menjadi orang tua yang ikhlas bisa ditempuh dengan beberapa cara,misalnya melakukan konseling kepada ahlinya. "Bagaimana caranya harus dibantu dengan konseling sampai ketemu ikhlas tadi."

Lebih mendalam lagi Kepala Sekolah memberikan informasinya terkait upaya sekolah dalam membina minat bakat siswanya yang melalui tari dan musik tersebut, bahwa dalam prateknya sekolah melaksanakan kegiatan tersebut selama satu minggu sekali, dan sama-sama bertepatan di hari jumat seperti yang dilakasanakan oleh guru mapel inklusi khususnya pada kelas 7 . Sekolah menyediakan upaya pembinaan minat bakat dari seki tari dan musik ini tidak hanya ditujukan untuk mereka siswa ABK saja namun juga untuk siswa reguler. Artinya baik siswa reguler dan juga siswa ABK memiliki kesempatan sama untuk mengembangkan minat bakat mereka di tari dan musik, namun juga mereka harus mampu bersaing antara siswa reguler dan ABK untuk menjadi yang terbaik dalam kegiatan tersebut.
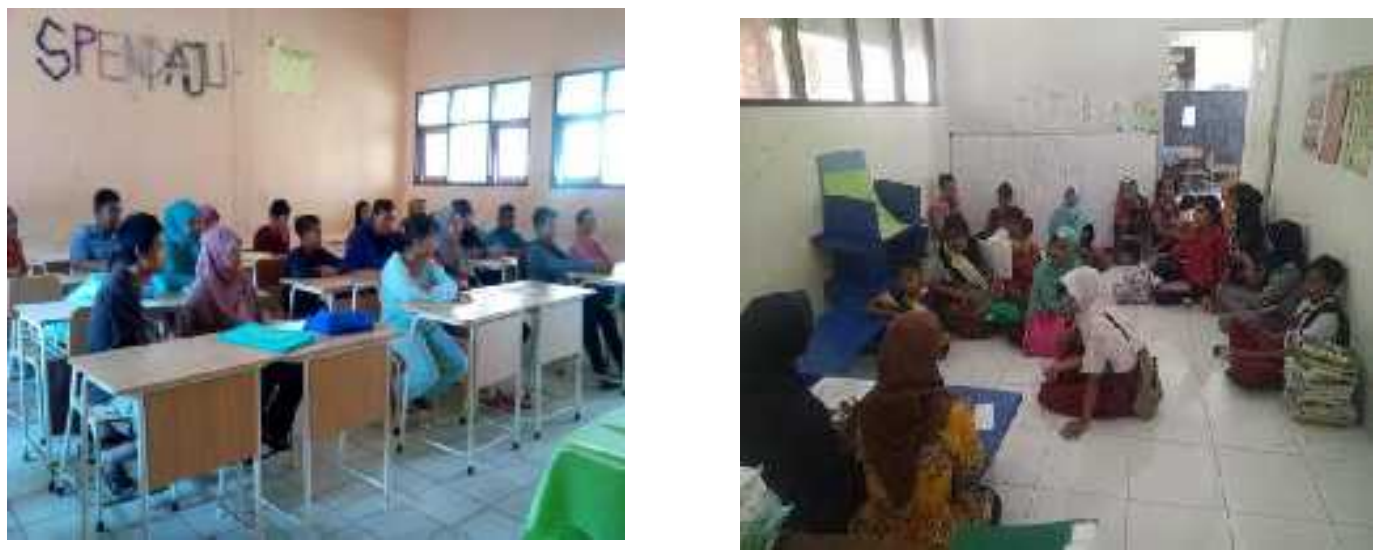

Gambar 1 Kegiatan Parenting bersama Orang Tua Siswa ABK dalam penanganan masalah minat bakat siswa ABK di SMP Negeri 27 Surabaya juga di lakukan dengan kegiatan konseling. 
Pada dasarnya manusia merupakan mahluk individu juga mahluk sosial. Manusia sebagai mahluk individu ketika menjadi sosok yang mandiri dan menyelesaikan segala persoalan yang telah dihadapinya. Dengan adanya konsep bahwa manusia diberikan akal dan dapat menganalisa persoalan yang dihadapi, sehingga permasalahan tersebut selesai. Dalam segi manusia sebagai mahluk sosial, sepintar, secanggih, dan sehebat apapun manusia menangani persoalan-persoalannya, pasti tardapat suatu masa dimana manusia itu lemah di titik terbawah bahkan minus.

Ketika saat-saat seperti itulah mereka membutuhkan sosok manusia lain untuk membantu menghadapi persoalan yang dihadapi, meskipun tidak semua manusia itu merasakan dan menyadari bahwa dirinya membutuhkan pertolongan, karena terdapat aspek-aspek egoisme yang disebut introvert dalam istilah psikologi. Ada hal yang juga patut dan wajib diketahui, bahkan dimengerti dengan baik oleh seorang konselor ketika menghadapi klien,karena terdapat berbagai macam latarbelakang seseorang yang harus dipahami dan ditangani dengan sepenuh hati dan tulus ikhlas, sehingga konselor dapat menjadi sosok yang hangat, menerangi, melindungi, dan juga mengarahkan klien untuk menuju dirinya yang sebenarnya.konselor, meskipun pada dasarnya klien yang ditangani, datang dengansendirinya bahwa dia akan bertemu konselor dan membahas permasalahannya

Ketika konselor mendapatkan seorang klien yang membutuhkan bantuan, dengan klien yang membutuhkan penanganan khusus seperti ABK, tentu saja dia tidak datang dengan sendirinya melainkan diantar, diajak, bahkan dipaksa oleh orang tua/rekan/saudaranya. Dengan harapan, akan mendapatkan bimbingan dan dapat menjalankan hariharinya dengan lebih baik. Karena peristiwa-peristiwa di atas itulah yang membuat Kurpius dan Robinson (1978), yang dikemukakan dalam buku Gunardi, bahwa peran konsultan/konselor adalah:

a. Sebagai pelatih atau pendidik. Seorang konsultan bisa diajak untuk mengajar ketrampilan seorang atau beberapa staf tertentu atau konsultan dalam pendidikan yang diminta mendidik guru-guru dalam dasar ketrampilan berkomunikasi.

b. Sebagai tenaga khusus yang ahli dalam bidangnya. Misalnya dalam dunia kedokteran, seorang pasien yang dikirim ke ahli yang lebih spesialistik untuk mediagnosis dan mungkin untuk terapi selanjudnya.

c. Sebagai juru penengah (negosiator). Yang menengahi kalau ada sesuatu ketidaksesuaian misalnya, pada suatu system yang dipakai klien mengalami kesulitan, konsultan bertindak sebagai fasilitator untuk berkomunikasi dan memberikan umpan-balik yang objektif terhdap sistemnya utuk kelancaran semua pihak.

d. Sebagai rekan (collaborator). Yang bertindak sebagai fasilitator pada proses pemecahan masalah setelah penentuan bersama mengenai sumber permasalahannya. Corak hubungan antara konsultan atau klien sangat penting karena konsultan bertindak sebagai rekan bagi klien dan mengajar klien bagaimana memecahkan masalah. 

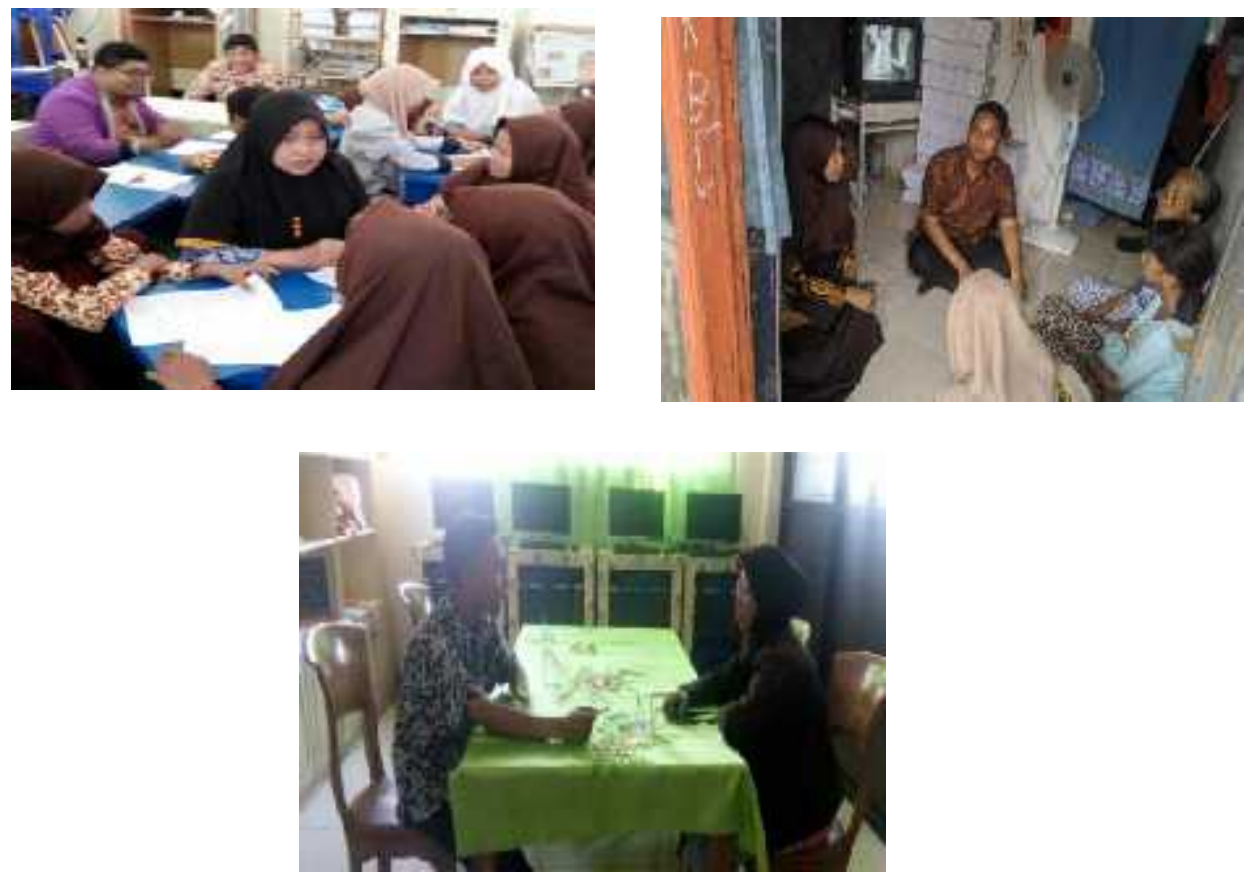

\section{Gambar 2 Kegiatan Konseling bersama Orag Tua dan Siswa ABK}

\section{Life Skill Education ( Pendidikan Kecakapan Hidup ) sangat di perlukan} untuk menggali potensi minta bakat siswa ABK di SMP Negeri 27 Surabaya.

Pendekatan Leaning By Doing Untuk Melatih Life Skill Bagi Anak Berkebutuhan Khusus Seperti banyak dipahami bahwa learning by doing adalah ketika anak-anak didik, sengaja dididik dengan mengkombinasikan sistem pemelajaran tutorial disertai dengan melakukannya, praktik lebih tepatnya. Dengan metode ini ternyata ada pengaruh yang signifikan terhadap perkembangan motorik anak. Khususnya kemampuan dalam menggerakkan fisiknya dalam melakukan proses pembelajaran. Secara tidak langsung guru telah mengarahkan siswa untuk mengombinasikan aspek kognitif, afektif maupun psikomotorik.

Berbeda sekali jika dibandingkan dengan pembelajaran yang hanya berkutat pada teori atau ceramah saja. Lebih dari itu, dengan metode ini anak akan mampu mendemonstrasikan pengalamannya secara langsung meskipun apa yang dilakukan melalui proses try and error. Ada beberapa metode dan model pembelajaran bagi anaka berkebutuhan khusus yang menekankan pada pengalaman siswa secara langsung, diantaranya adalah:

a) Metode proyek : metode ini sangat mungkin diterapkan, karena metode proyek merupakan salah satu cara pemberian pengalaman belajar dengan menghadapkan anak dengan persoalan sehari-hari untuk dipecahkan secara kelompok. Dalam pelaksanaanya, metode proyek memposisikan guru sebagai fasilitator yang harus menyediakan alat dan bahan untuk melaksanakan "proyek" yang berorientasi pada kebutuhan dan minat siswa dan menantang siswa untuk mencurahkan segala kemampuan, keterampilan serta kreativitasnya. 
b) Metode eksperimen juga termasuk metode yang menggunakan pendekatan Learning by Doing, karena metode eksperimen merupakan cara pengajaran dimana guru dan murid bersama-sama melakukan suatu latihan atau percobaan untuk mengetahui pengaruh atau akibat dari suatu aksi.

c) Metode karya wisata adalah suatu cara penguasaan bahan pelajaran oleh para siswa dengan jalan membawa mereka langsung ke objek yang terdapat diluar kelas atau dilingkungan kehidupan nyata, agar mereka dapat mengamati atau mengamati secara langsung.
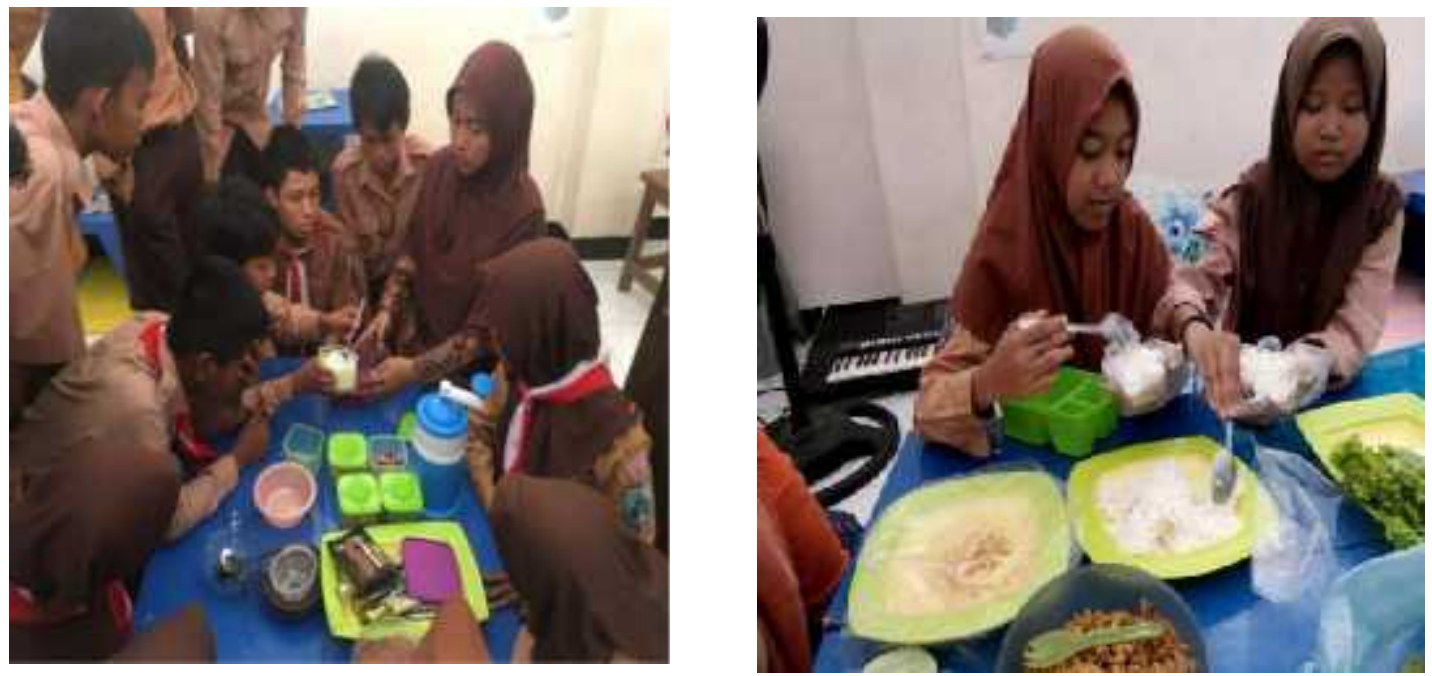

Gambar 3. Kegiatan Cooking class
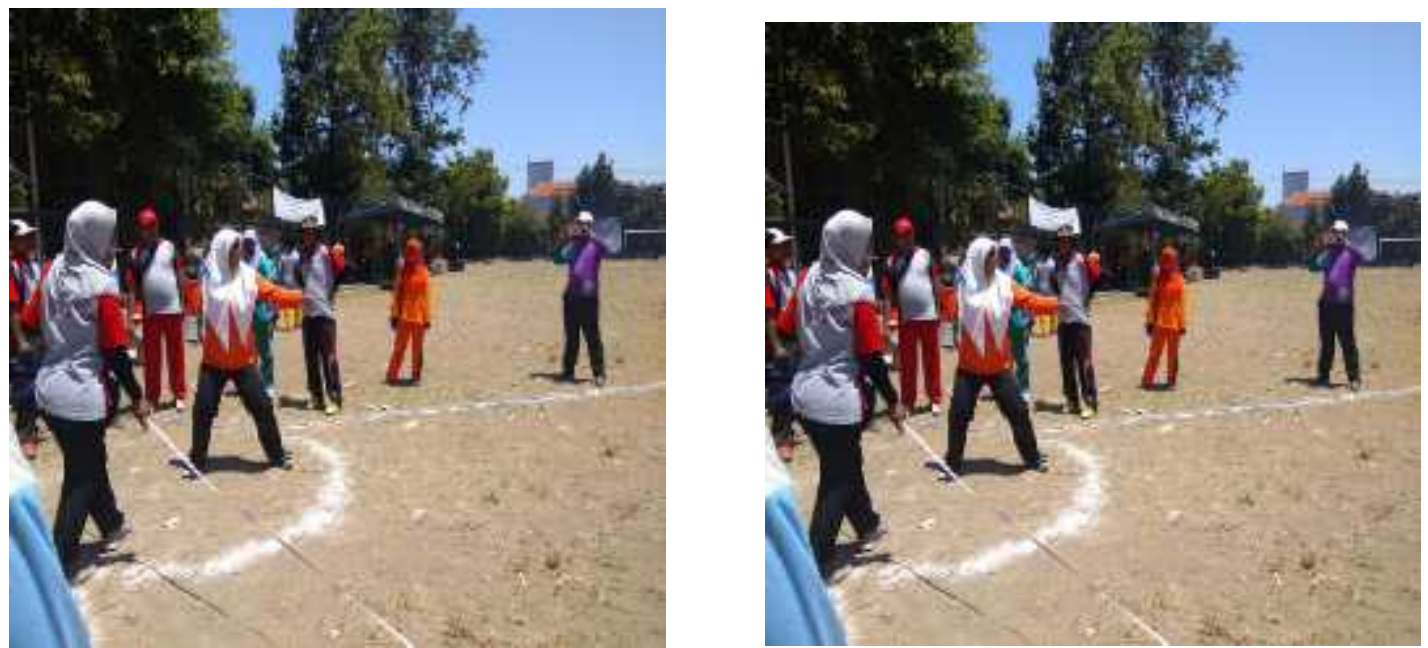

Gambar 4. Kegiatan Olahraga Tradisional (Oltrad) 


\section{KESIMPULAN DAN SARAN}

\section{A. Kesimpulan}

Penyelenggaraan Inklusi pada dasarnya bertujuan untuk membantu peserta didik yang menyandang kelainan fisik, mental, dan perilaku, agar mampu mengembangkan sikap pengetahuan dan keterampilan sebagai pribadi maupun anggota masyarakat dalam mengadakan hubungan timbal balik dengan lingkungan sosial, budaya dan alam sekitar serta dapat mengembangkan kemampuan dalam dunia kerja atau mengikuti pendidikan lanjut. Salah satu upaya pemerintah untuk memberikan pelayanan pada anak-anak luar biasa adalah dengan dirintisnya pendidikan khusus dan pelayanan khusus. Konsep pendidikan khusus dan pendidikan layanan khusus akan memberikan warna dan manajemen pendidikan luar biasa yang menuju pada suatu layanan mutu dan terpadu khususnya dalam pola pelayanan pendidikan dan rehabilitasi.

SMP Negeri 27 Surabaya salah satu SMP yang ditunjuk untuk menyelenggarakan pendidikan khusus dan pendidikan layanan khusus. SMP Negeri 27 Surabaya didirikan melalui keputusan Menteri Pendidikan dan Kebudayaan Republik Indonesia No. 051/O/1083 tentang Organisasi dan Tata Kerja Sekolah Luar Biasa Pembina SMP Negeri 27 Surabaya telah mengidentifkasikan dan merencanakan kegiatan-kegiatan operasional yang secara langsung mempengaruhi mutu serta menjamin bahwa proses belajar mengajar dan proses-proses yang terkait dilaksanakan pengendalian dan memadai setiap proses dipastikan terlebih dahulu dibuat perencanaan, dimonitor dan dievaluasi secara periodik sesuai perkembangan pelaksanaan. produk fungsi-fungsi tersebut yang pada akhirnya bertujuan untuk pencapaianm kebijakan mutu yang telah ditetapkan. Mengingat kondisi anak luar biasa, maka pekerjaan yang berhubungan dengan pelayanan terhadap anak luar biasa, khususnya guru harus memiliki dedikasi yang tinggi, pengetahuan dan keterampilan yang sesuai dengan kebutuhan pelayanan luar biasa (anak tunagrahita). Proses belajar-mengajar, guru sangat memegang peranan yang cukup penting. Fungsi guru bagi anak tunagrahita pertama-tama adalah membimbing anak didiknya ke arah perkembangan yang positif. Ketika membimbing guru harus menggunakan cara yang tepat dalam usaha mencapai tingkat kemampuan yang optimal, sehingga mendekati derajat kemampuan anak biasa pada umumnya.

Sekolah adalah orang tua kedua bagi anak berkebutuhan khusus, orang yang memperhatikan perkembangan anak didiknya dan orang tua adalah orang yang mendukung dan memperhatikan anaknya di rumah. Untuk itu guru dan orang tua adalah orang yang cukup berperan penting bagi pertumbuhan dan perkembangan anak tunagrahita untuk berkreativitas dan terampil sesuai dengan minat dan bakat yang mereka miliki. Peran guru dan orang tua, tentu tidak berjalan seperti apa yang mereka harapkan. Ada faktor yang mendukung peran guru dan orang tua dalam mengembangkan minat dan bakat anak tunagrahita, ada juga faktor yang menghambat peran guru dan orang tua dalam mengembangkan minat dan bakat anak tunagrahita. Faktor yang mendukung peran guru dan orang tua dalam mengembangkan minat dan bakat anak tunagrahita terbagi menjadi dua yaitu faktor internal dan faktor eksternal. 
Faktor internal yaitu, fasilitas sekolah, sumber daya manusia (guru), anak tunagrahita (input), dan lingkungan keluarga, sedangkan faktor eksternal yaitu, kerjasama antar lembaga dan kerjasama antara guru dan orang tua. Kemudian, faktor yang menghambat peran guru dan orang tua dalam mengembangkan minat dan bakat anak tunagrahita adalah kondisi fisik anak tunagrahita dan keadaan perekonomian anak tunagrahita.

\section{B. Saran}

Berdasarkan penelitian tentang peran guru dan orang tua dalam mengembangkan minat dan bakat anak tunagrahita di SMP Negeri 27 Surabaya maka diperoleh beberapa saran.

\section{Kepala Sekolah SMP Negeri 27 Surabaya}

Lebih diperhatikan lagi anak-anak murid atau siswa yang ketika pulang sekolah tidak pulang dengan jalan kaki sendiri sebelum dijemput oleh orang tua atau wali dari mereka, sebab sangat rentan atau berbahaya bagi mereka untuk jalan dijalan-jalan raya sendirian. Kelas keterampilan tanaman hias lebih di efektifkan lagi agar tidak kalah menarik dengan kelas-kelas keterampilan lainnya, sebab apabila mereka hanya belajar dikelas saja dan hanya mendengarkan ceramah dari guru tanpa seringnya praktek seperti kelas-kelas keterampilan lainnya itu akan membuat siswa jenuh dengan gaya belajar mencatat dan mendengarkan guru menjelaskan (lebih inovatif lagi).

Lebih ditingkatkan lagi hubungan kerjasama dengan lembaga-lembaga lain yang mungkin bisa menjadi donatur tetap di sekolah, agar siswa ataupun sekolah bisa terus mengembangkan karya-karya dari anak tunagrahita itu sendiri.Hubungan ataupun kerjasama yang lebih komunikatif lagi antara pihak SMP Negeri 27 Surabaya dengan orang tua dalam memperhatikan perkembangan anak didiknya, agar orang tua ataupun pihak sekolah bisa saling mengasih masukan dan saling mengingatkan bagaimana yang terbaik untuk anak didiknya ataupun untuk si anak sendiri.

\section{Guru-guru SMP Negeri 27 Surabaya}

Jangan terlalu keras kepada anak-anak didiknya ketika proses belajarmengajar berlangsung, karena Anak Inklusi adalah anak yang harus dihadapai dengan rasa kasih sayang tinggi dan kelembutan, serta kesabaran.Guru harus memiliki kemauan dan cara tersendiri agar ketika belajar peserta didik tidak merasa jenuh atau bosan, memiliki apresiasi yang mengajak atupun mengikutkan peserta didik kedalam materi-materi ataupun bahan ajaran yang sedang berlangsung. Guru harus sering-sering melakukan komunikasi kepada orang tua tentang perkembangan akademik anak dikelas maupun hal-hal yang berkaitan dengan perkembangan anak, misalnya dalam mengerjakan PR (Pekerjaan Rumah) dan lain sebgainya.

Guru dan orang tua, harus sering mealukan pertemuan rutin secara formal, guna memperhatikan perkembangan anak tunagrahita di sekolah. Guru harus menanamkan nilai-nilai moral dan kedisiplinan kepada anak secara tidak langsung 
ketika proses belajar mengajar dan sekaligus mencontohnkannya agar si anak paham dan mengerti.

\section{Orang Tua Penerima Manfaat}

Orang tua harus selalu memberi perhatian yang lebih kepada anak, terutama jangan telat ketika menjemput anak ke sekolah. Sangat berbahaya bila membiarkannya pulang ke rumah sendirian dengan jalan kaki ataupun naik kenderaan umum sendiri. Jika mampu fasilitasilah anak di rumah dengan memberikan media atau alat yang mendukung perkembangan kreativitas atau keterampilannya, seperti mesin jahit dan lain sebagainya. Agar anak bisa terus mengaplikasikan ilmu yang telah ia dapatkan di sekloah. Orang tua harus lebih sering komunikasi dengan pihak sekolah baik guru maupun bagian kesiswaan, agar orang tua tahu bagaimana perkembangan anak di sekolah dan dapat mengimbanginya atau menyerasikannya di rumah.

\section{DAFTAR PUSTAKA}

Affifudin dan Beni Ahmad. 2009. Metode Penelitian Kualitatif. Bandung: Pustaka Setia.

Ahmad Susanto. 2014. Teori Belajar dan Pembelajaran di Sekolah Dasar, (Jakarta: Kencana Prenada Media Group)

Akbar Hawadi R. 2004. Psikologi Perkembangan Anak Mengenal Sifat, Bakat, Kemampuan Anak. Jakarta: Grasindo.

Khodijah, Nyayu. 2014. Psikologi Pendidikan. Jakarta: Rajawali Pers.

Lexy J. Moleong. 2008. Metode Penelitian Kualitatif. Bandung: Remaja Rosdakarya. Mohammad Efendi. 2006. Pengantar Psikopedagogik Anak Berkelainan.

Sardiman. 2010. Interaksi dan Motivasi Belajar Mengajar. Jakarta: Rajawali Pers. Soerjono Soekanto. 2006. Sosiologi Suatu Pengantar. Jakarta: Raja Grafindo Persada. S. Nasution. 2000. Metode Research (Penelitian Ilmiah). Jakarta: Bumi Aksara.

Sugihartono, dkk. 2007. Psikologi Pendidikan. Yogyakarta: UNY Press.

Sugiyono. 2010. Metode Penelitian Pendekatan Kualitatif. Bandung: Alfabeta.

Susanto, ahmad. 2013. Teori Belajar dan Pembelajaran di Sekolah Dasar. Jakarta: Kencana prenada media group.

Syaiful Bahri Djamarah. 2000. Guru dan Anak Didik Dalam Interaksi Edukatif..Jakarta: Rineka Cipta.

Tin Suharmini. 2009. Psikologi Anak Berkebutuhan Khusus. Yogyakarta: Kanwa Publisisher. 